\title{
(5)
}

УДК 612.3:591.413.2

\section{КОНЦЕПЦІЯ $\mathrm{Ca}^{2+}$ ФУНКЦІОНАЛЬНИХ ОДИНИЦЬ У ЗАСТОСУВАННІ ДО СЕКРЕТОРНИХ КЛІТИН СЛИННИХ ЗАЛОЗ ЛИЧИНКИ CHIRONOMUS PLUMOSUS}

\author{
В. В. Манько \\ Львівський національний університет імені Івана Франка \\ вул. Грушевського, 4, Львів 79005, Україна \\ e-mail: vvmanko@franko.Iviv.ua
}

Виходячи з аналізу експериментальних даних, отриманих у ході дослідження $\mathrm{Ca}^{2+}$-транспортувальних систем секреторних клітин слинних залоз личинки Chironomus plumosus, запропоновано концепцію $\mathrm{Ca}^{2+}$-функціональних одиниць. Згідно з нею, $\mathrm{Ca}^{2+}$-функціональна одиниця - це абстрактна модель, яка складається зі системи активного і системи пасивного транспортування $\mathrm{Ca}^{2+}$ та мембрани, що забезпечує компартменталізацію цих катіонів. Са ${ }^{2+}$-функціональні одиниці $€$ I (системи активного і пасивного транспортування належать одній мембрані) і II типу (системи активного і пасивного транспортування належать різним мембранам однієї клітини). В обох випадках $\mathrm{Ca}^{2+}$-функціональна одиниця $€$ не статичною структурою, а динамічною системою, яка забезпечує підтримання відповідної $\left[\mathrm{Ca}^{2+}\right]$ у цитозолі та може перебувати у трьох станах. Стан спокою характеризується наявністю динамічної рівноваги між вхідним і вихідним потоками $\mathrm{Ca}^{2+}$. У стані активності вхідний (відносно цитозолю) потік $\mathrm{Ca}^{2+}$ переважає над вихідним, а у стані інактивації навпаки, переважає вихідний потік. Чинниками, які за рахунок прямого позитивного чи зворотного негативного зв'язку забезпечують перехід $\mathrm{Ca}^{2+}$-транспортувальних систем між різними станами, слугують катіони $\mathrm{Ca}^{2+}$, оскільки активність більшості $\mathrm{Ca}^{2+}$-транспортувальних систем залежить від їхньої цитозольної концентрації.

Ендоплазматична $\mathrm{Ca}^{2+}$-функціональна одиниця досліджуваних секреторних клі-

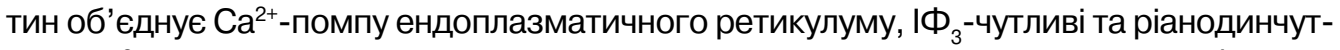
ливі $\mathrm{Ca}^{2+}$-канали. Як наслідок, 1) додавання ріанодину до середовища інкубування залоз у субмікромолярній концентрації спричиняє збільшення вмісту $\mathrm{Ca}^{2+}$ у їхній тканині; 2) стимуляція $І Ф_{3}$-чутливих $\mathrm{Ca}^{2+}$-каналів запобігає одночасній стимуляції ріанодинчутлвих $\mathrm{Ca}^{2+}$-каналів чи навпаки; 3) гепарин спричиняє збільшення вмісту $\mathrm{Ca}^{2+}$ у тканині залоз, оброблених сапоніном, але лише за наявності у середовищі ріанодину в активуючій ріанодинчутливі $\mathrm{Ca}^{2+}$-канали концентрації.

$\mathrm{Ca}^{2+}$-функціональну одиницю плазматичної мембрани формують потенціалкеровані $\mathrm{Ca}^{2+}-$ канали, $\mathrm{Na}^{+}-\mathrm{Ca}^{2+}$-обмінник і $\mathrm{Ca}^{2+}$-помпа плазматичної мембрани. 
Це припущення базується на тому факті, що між потенціалкерованими $\mathrm{Ca}^{2+}$ каналами та $\mathrm{Na}^{+}-\mathrm{Ca}^{2+}$-обмінником, з одного боку, та $\mathrm{Na}^{+}-\mathrm{Ca}^{2+}$-обмінником і $\mathrm{Ca}^{2+}$ помпою плазматичної мембрани, з другого, існують тісні функціональні зв'язки навіть за умов внутрішньоклітинної перфузії. До певної міри стан цієї $\mathrm{Ca}^{2+}$ функціональної одиниці визначається залежністю $\mathrm{Na}^{+}-\mathrm{Ca}^{2+}$-обміну від активності $\mathrm{Na}^{+}-\mathrm{K}^{+}$-помпи. ІІї характерною ознакою $€$ також залежність від рівня мембранного потенціалу, а не лише від цитозольної $\left[\mathrm{Ca}^{2+}\right]$.

Певні $\mathrm{Ca}^{2+}$-транспортувальні системи можуть входити до кількох $\mathrm{Ca}^{2+}$ функціональних одиниць. Ендоплазматично-мітохондріальна $\mathrm{Ca}^{2+}$-функціональна одиниця складається з каналів вивільнення $\mathrm{Ca}^{2+}$ ендоплазматичного ретикулуму та $\mathrm{Ca}^{2+}$-уніпортера мітохондрій, оскільки дія на вміст $\mathrm{Ca}^{2+}$ у тканині слинних залоз ріанодину та рутенію червоного, а також $І \Phi_{3}$ та рутенію червоного за умов поєднання їх у середовищі інкубації є неадитивною.

Постульовану концепцію можна розглядати як робочу гіпотезу для з'ясування ролі, яку відіграє узгодженість функціонування різних $\mathrm{Ca}^{2+}$-транспортувальних систем у $\mathrm{Ca}^{2+}$-сигналізації і не лише у секреторних клітинах екзокринних залоз.

Ключові слова: $\mathrm{Ca}^{2+}$-функціональні одиниці, $\mathrm{Na}^{+}-\mathrm{Ca}^{2+}$-обмінник, $\mathrm{Ca}^{2+}$-помпа, потенціалкеровані $\mathrm{Ca}^{2+}$-канали, ІФ -чутливі $\mathrm{Ca}^{2+}$-канали, ріанодинчутливі $\mathrm{Ca}^{2+}$-канали, $\mathrm{Ca}^{2+}$-уніпортер, секреторні клітини, концепція.

\section{$\mathrm{Ca}^{2+}$-FUNCTIONAL UNITS CONCEPTION CONCERNING TO SECRETORY CELL OF CHIRONOMUS PLUMOSUS LARVAE SALIVARY GLAND}

V. V. Manko

Ivan Franko National University of Lviv 4, Hrushevskyi St., Lviv 79005, Ukraine

On the basis of analysis of experimental data received during investigation of $\mathrm{Ca}^{2+}$-transporting systems of secretory cells of salivary glands of Chironomus plumosus larvae, a conception of $\mathrm{Ca}^{2+}$-functional units has been proposed. According to this conception, $\mathrm{Ca}^{2+}$-functional unit is an abstract model which consists of with active and passive $\mathrm{Ca}^{2+}$-transporting systems and cellular membrane providing $\mathrm{Ca}^{2+}$ cations compartmentalisation. There are type I (active and passive transporting systems located in the same membrane) and type II (active and passive transporting systems located in different membranes of the same cell) $\mathrm{Ca}^{2+}$-functional units. In both cases, $\mathrm{Ca}^{2+}$-functional unit is not a static structure, but a dynamic one, that ensure proper $\left[\mathrm{Ca}^{2+}\right]$ support in cytosol. It may be in three states: 1) resting state the is characterised by a dynamic balance between the influx and efflux of $\mathrm{Ca}^{2+}$ flow; 2) active state of $\mathrm{Ca}^{2+}$ influx (regarding cytosol) prevailing over the efflux; 3 ) inactive state (oppositely, $\mathrm{Ca}^{2+}$ efflux prevailing over its influx). Factors which due to direct positive or negative feedback are supporting $\mathrm{Ca}^{2+}$-transporting systems transition 
between different states, are $\mathrm{Ca}^{2+}$ cations, since the activity of majority of $\mathrm{Ca}^{2+}$-transporting systems depends on cytosol concentration of $\mathrm{Ca}^{2+}$.

Endoplasmic $\mathrm{Ca}^{2+}$-functional unit of investigated secretory cells combines $\mathrm{Ca}^{2+}$ pump of endoplasmic reticulum, $\operatorname{Ins}_{3} \mathrm{Rs}$ and RyRs. As a result of 1 ) ryanodine adding to incubatory medium of glands in submicromolar concentration causes $\mathrm{Ca}^{2+}$ content increasing in their tissue; 2) $\operatorname{lnsP}_{3}$ Rs stimulation prevents simultaneous RyRs stimulation or contrariwise; 3 ) heparin causes $\mathrm{Ca}^{2+}$ content increasing in gland tissue, treated with saponin, but only in ryanodine presence in medium in concentration activating RyRs.

$\mathrm{Ca}^{2+}$-functional unit of plasma mambrane are formed by voltage-operated $\mathrm{Ca}^{2+}$ channels, $\mathrm{Na}^{+}-\mathrm{Ca}^{2+}$ exchanger and $\mathrm{Ca}^{2+}$-pump of plasma membrane. That assumption is based on the fact that between the voltage-operated $\mathrm{Ca}^{2+}$-channel and $\mathrm{Na}^{+}-\mathrm{Ca}^{2+}$ exchanger, from one side, and $\mathrm{Na}^{+}-\mathrm{Ca}^{2+}$ exchanger and $\mathrm{Ca}^{2+}$-pump of plasma membrane, from the other side, tight functional links are existing even in case of intracellular perfusion. To some extent, condition of this $\mathrm{Ca}^{2+}$-functional unit are defined by $\mathrm{Na}^{+}-$ $\mathrm{Ca}^{2+}$ exchange dependence on $\mathrm{Na}^{+}-\mathrm{K}^{+}$pump activity. Its peculiar feature is also a dependence on membrane potential level, not only on cytosolic $\left[\mathrm{Ca}^{2+}\right]$.

Distinct $\mathrm{Ca}^{2+}$-transporting systems may be a part of several $\mathrm{Ca}^{2+}$-functional units. Endoplasmic-mitochondrial $\mathrm{Ca}^{2+}$-functional unit consists of $\mathrm{Ca}^{2+}$-release channels of endoplasmic reticulum and mitochondrial $\mathrm{Ca}^{2+}$-uniporter, so far as influence of ryanodine and ruthenium red, and also $\operatorname{InsP}_{3}$ and ruthenium red under the condition of their combination in incubation medium with $\mathrm{Ca}^{2+}$ content of salivary glands tissue is not additive.

Postulated conception could be positioned as a working hypothesis for identification of the role of different $\mathrm{Ca}^{2+}$-transporting systems in coordination of $\mathrm{Ca}^{2+}$ signalling in different cells other than secretory cells of exocrine glands.

Key words: $\mathrm{Ca}^{2+}$-functional unit, $\mathrm{Na}^{+}-\mathrm{Ca}^{2+}$ exchanger, $\mathrm{Ca}^{2+}-$ pump, voltageoperated $\mathrm{Ca}^{2+}$-channels, InsP ${ }_{3} \mathrm{R}, \mathrm{RyR}, \mathrm{Ca}^{2+}$-uniporter, secretory cells.

\section{ВСТУП}

Використовуючи різні методичні підходи у плазматичній мембрані секреторних клітин слинних залоз личинки Chironomus plumosus, ідентифіковано потенціалкеровані $\mathrm{Ca}^{2+}$-канали $[4,8,18], \mathrm{Na}^{+}-\mathrm{Ca}^{2+}$-обмінник $[6,12,17]$ і $\mathrm{Ca}^{2+}$-помпу плазматичної мембрани $[9,16]$. Доведено також наявність $\mathrm{Ca}^{2+}$-помпи ендоплазматичного ретикулуму $[13,16]$ Са $^{2+}$-уніпортера мітохондрій [20], ІФ -чутливих та ріанодинчутливих $\mathrm{Ca}^{2+}$-каналів $[1,11,13]$. Роль первинного агоніста у слинних залозах комара-дергуна може відігравати АТФ, оскільки на плазматичній мембрані досліджуваних секреторних клітин ідентифіковані P2Y- і Р2Х-рецептори [14].

У ході дослідження властивостей цих $\mathrm{Ca}^{2+}$-транспортувальних систем з'ясувалося, що деякі їхні властивості неможливо пояснити без урахування тих складних взаємовідносин, які існують між ними. Так, встановлено, що амплітуда потенціалкерованого $\mathrm{Ca}^{2+}$-струму залежить від функціональної активності $\mathrm{Na}^{+}-$ $\mathrm{Ca}^{2+}$-обмінника плазматичної мембрани [5]. У свою чергу, амплітуда вхідного струму $\mathrm{Na}^{+}-\mathrm{Ca}^{2+}$-обміну збільшується внаслідок додавання до внутрішньоклітинного розчину блокатора $\mathrm{Ca}^{2+}$-помпи еозину $\mathrm{Y}$ [15]. Існують також складні 
взаємовідносини між каналами вивільнення $\mathrm{Ca}^{2+}$ із внутрішньоклітинних депо $І Ф_{3}$-чутливими та ріанодинчутливими [1], а також між каналами вивільнення $\mathrm{Ca}^{2+}$ та $\mathrm{Ca}^{2+}$-уніпортером мітохондрій [2]. Це наштовхнуло нас на думку про необхідність пошуку загальних закономірностей між встановленими фактами.

\section{МАТЕРІАЛИ І МЕТОДИ ДОСЛІДЖЕНЬ}

У роботі проаналізовано експериментальні дані, отримані раніше з метою ідентифікації та встановлення властивостей ріанодинчутливих та ІФ каналів ендоплазматичного ретикулуму $[1,13]$, потенціалкерованих $\mathrm{Ca}^{2+}$-каналів $[5,7], \mathrm{Na}^{+}-\mathrm{Ca}^{2+}$-обмінника $[15,19]$ плазматичної мембрани та $\mathrm{Ca}^{2+}$-уніпортера мітохондрій [2] секреторних клітин слинних залоз личинки Chironomus plumosus.

Властивості ріанодинчутливих і ІФ тера мітохондрій, досліджували, аналізуючи зміни вмісту $\mathrm{Ca}^{2+}$ у тканині залоз після їхнього інкубування з відповідним активатором чи блокатором - ріанодином (5 або 500 нмоль/л), ІФ (10 мкмоль/л), гепарином (500 мкг/мл) чи рутенієм червоним (10 мкмоль/л) [13, 20].

Струм через потенціалкеровані $\mathrm{Ca}^{2+}$-канали досліджували з використанням методу фіксації потенціалу за умов внутрішньоклітинної перфузії [4]. Застосовуючи цей метод реєстрували і струм $\mathrm{Na}^{+}-\mathrm{Ca}^{2+}$-обміну - у відповідь на раптове гіперполяризувальне зміщення мембранного потенціалу плазматичної мембрани (детальніше див. [12]). У цих дослідженнях використовували блокатор $\mathrm{Ca}^{2+}$-помп еозин Ү (10 мкмоль/л) і $\mathrm{Na}^{+}-\mathrm{K}^{+}$-помпи уабаїн (25 мкмоль/л), а також АТФ (1 ммоль/л) і відновлений глутатіон (GSH, 1 ммоль/л). Достовірність різниці між двома статистичними групами визначали за Стьюдентом [3]. Інші умови проведення експериментальних досліджень наведені у підписах до рисунків.

\section{РЕЗУЛЬТАТИ ДОСЛІДЖЕННЯ ТА ЇХНЄ ОБГОВОРЕННЯ}

\section{Концепція $\mathrm{Ca}^{2+}$-функціональних одиниць}

У тих випадках, коли система є досить складною, ії треба, для полегшення опису процесів у ній, спростити до „ідеальної системи”. Якщо йдеться про підтри-

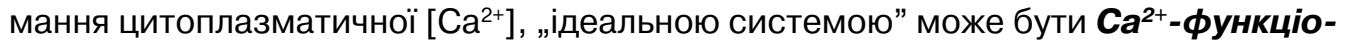

\section{нальна одиниця.}

У найпростішому випадку ця абстрактна модель складається з одного $\mathrm{Ca}^{2+}$ каналу (системи пасивного транспортування), $\mathrm{Ca}^{2+}-$ помпи (системи активного транспортування) та мембрани, що забезпечує компартменталізацію катіонів $\mathrm{Ca}^{2+}$.

Власне будь-яку ділянку клітини цілком доречно абстрагувати до такої $\mathrm{Ca}^{2+}$ функціональної одиниці. За структурою їх можна поділити на два типи. $\mathrm{Ca}^{2+}$ функціональну одиницю I типу формують системи активного і пасивного транспортування однієї мембрани, наприклад, $\mathrm{Ca}^{2+}$-канали і $\mathrm{Ca}^{2+}$-помпа ендоплазматичного ретикулуму або $\mathrm{Ca}^{2+}$-канали і $\mathrm{Ca}^{2+}$-помпа плазматичної мембрани.

До складу $\mathrm{Ca}^{2+}$-функціональної одиниці // типу входять система активного і система пасивного транспортування, які належать різним мембранам однієї клітини, наприклад, $\mathrm{Ca}^{2+}$-канали плазматичної мембрани і $\mathrm{Ca}^{2+}$-помпа ендоплазматичного ретикулуму. Принципової відмінності у властивостях між $\mathrm{Ca}^{2+}$-функціо- 
нальними одиницями двох типів немає (або нам про це нічого невідомо). Тому така класифікація $є$ досить-таки умовною і необхідною для кращого розуміння цього поняття.

Набагато важливіше звернути увагу на те, що $\mathrm{Ca}^{2+}$-функціональна одиниця $€$ не статичним утвором (структурою), а динамічною системою, яка забезпечує підтримання відповідної $\left[\mathrm{Ca}^{2+}\right]$ у цитозолі та може перебувати у трьох станах спокою, активності й інактивації. Більше того, збільшення цитозольної $\left[\mathrm{Ca}^{2+}\right.$, яке спостерігається при переході $\mathrm{Ca}^{2+}$-функціональної одиниці зі стану спокою у стан активності, $є$ обмежене в просторі та швидкоплинне і називається локальним $\mathrm{Ca}^{2+}$-спайком, пафом чи спарком.

У свою чергу, чинниками, які за рахунок прямого позитивного чи зворотного негативного зв'язку забезпечують перехід $\mathrm{Ca}^{2+}$-транспортувальних систем між різними станами, в основному слугують катіони $\mathrm{Ca}^{2+}$, оскільки активність більшості $\mathrm{Ca}^{2+}$-транспортувальних систем залежить від їхньої цитозольної концентрації.

Рівень $\mathrm{Ca}^{2+}$ у цитозолі $є$ результатом двох протилежно спрямованих потоків $\mathrm{Ca}^{2+}$. Вхідний потік (відносно цитозолю, $P_{\text {in }}$ ) забезпечує надходження позаклітинного $\mathrm{Ca}^{2+}$ через плазматичну мембрану чи його вивільнення 3 внутрішньоклітинних депо і реалізується функціонуванням пасивних $\mathrm{Ca}^{2+}$-транспортувальних систем. Протилежно спрямований вихідний потік $\left(P_{\text {out }}\right)$ забезпечує зменшення цитозольної $\left[\mathrm{Ca}^{2+}\right]$ за рахунок його активного виведення у позаклітинне середовище і/чи у внутрішньоклітинні депо.

У стані спокою (фізіологічного спокою) між цими потоками існує динамічна рівновага:

$$
P_{\text {in }}=P_{\text {out }},
$$

але завжди, на чому слід особливо наголосити, і $P_{\text {in }}>0$, i $P_{\text {out }}>0$. Тому $\mathrm{Ca}^{2+}-$ функціональна одиниця є справді динамічною системою.

Дія гормону чи медіатора спричиняє збільшення вхідного потоку, рівновага порушується і $\mathrm{Ca}^{2+}$-функціональна одиниця переходить у стан активності:

$$
P_{\text {in }}>P_{\text {out }}
$$

Тим не менше, такий стан є короткотривалим (нестабільним), оскільки локальне зростання цитозольної $\left[\mathrm{Ca}^{2+}\right]$ спричиняє збільшення вихідного потоку. Не настає також і рівновага на новому, енергетично вищому рівні, оскільки паралельно до активування цитозольним $\mathrm{Ca}^{2+}$ систем вихідного потоку відбувається пригнічення ним, за рахунок зворотних негативних зв'язків, систем вхідного потоку - настає стан інактивації:

$$
P_{\text {in }}<P_{\text {out }}
$$

Наслідком такого функціонування системи є зниження цитозольної [Ca $\left.{ }^{2+}\right]$ до стану фізіологічного спокою, коли ці катіони не можуть слугувати чинниками ні прямого позитивного, ні зворотного негативного зв'язку. Система повертається до стану динамічної рівноваги, описаної рівнянням (1).

У деяких випадках стан $\mathrm{Ca}^{2+}$-функціональної одиниці може визначатися не лише рівнем цитозольного $\mathrm{Ca}^{2+}$, але і значенням мембранного потенціалу. Зокрема, тоді, коли до складу $\mathrm{Ca}^{2+}$-функціональних одиниць входять Са ${ }^{2+}$-траспортувальні системи плазматичної мембрани, які мають виражену потенціалозалежність - потенціалкеровані $\mathrm{Ca}^{2+}$-канали чи $\mathrm{Na}^{+}-\mathrm{Ca}^{2+}$-обмінник. 
За дії будь-якого стимулятора $\mathrm{Ca}^{2+}$-функціональна одиниця відповідає як єдине ціле. Функціонування $\mathrm{Ca}^{2+}$-транспортувальної системи не у складі $\mathrm{Ca}^{2+}$-функціональної одиниці є неефективним, тому що за таких умов не може бути забезпечена дискретність $\mathrm{Ca}^{2+}$-сигналу. Надходження $\mathrm{Ca}^{2+}$ у цитозоль чи внутрішньоклітинними каналами, чи каналами плазматичної мембрани буде супроводжуватися лише статичним збільшенням його концентрації. Аналогічно, збільшення активності $\mathrm{Ca}^{2+}$-помпи чи $\mathrm{Na}^{+}-\mathrm{Ca}^{2+}$-обмінника спричинить лише зниження цитозольної $\left[\mathrm{Ca}^{2+}\right]$ до того рівня, наскільки дозволить це зробити їхня спорідненість до $\mathrm{Ca}^{2+}$. I лише за узгодженого функціонування систем пасивного й активного транспортування, об'єднаних у $\mathrm{Ca}^{2+}$-функціональну одиницю, можливим є генерування $\mathrm{Ca}^{2+}$-сигналу.

\section{Ендоплазматична $\mathrm{Ca}^{2+}$-функціональна одиниця}

У секреторних клітинах слинних залоз личинки комара-дергуна ІФ -чутливі та ріанодинчутливі $\mathrm{Ca}^{2+}$-канали разом з $\mathrm{Ca}^{2+}$-помпою мембрани ендоплазматичного ретикулуму формують ендоплазматичну $\mathrm{Ca}^{2+}$-функціональну одиницю, яка за структурою належить до I типу (рис. 1). За відсутності агоніста спонтанне вивільнення $\mathrm{Ca}^{2+}$ ріанодинчутливими каналами у цитозоль $\left(\mathrm{Ca}^{2+}\right.$-індуковане вивільнення $\mathrm{Ca}^{2+}$ ) компенсується його транспортуванням помпою у люмен ендоплазматичного ретикулуму, тому фізіологічна відповідь не виникає. Встановлюється певна динамічна рівновага між двома постійними потоками $\mathrm{Ca}^{2+}$.

Звичайно, такі принципи організації функціонування $\mathrm{Ca}^{2+}$-транспортувальних систем передбачають витрати великої кількості енергії. Але власне завдяки цьому локальне збільшення цитозольної $\left[\mathrm{Ca}^{2+}\right]$ підтримує чутливість $\mathrm{Ca}^{2+}$-функціональної одиниці до $Ф_{3}$ (i, відповідно, цілої клітини до агоніста) на досить високому рівні (рис. 1, А). Як наслідок, навіть незначне зростання ІФ у цитозолі спричиняє зміщення рівноваги у бік вивільнення $\mathrm{Ca}^{2+}$ із депо (рис. 1, Б).

Однак цей процес обмежений у часі, оскільки високі $\left[\mathrm{Ca}^{2+}\right]$ пригнічують обидва типи каналів (рис. 1, B), запобігаючи надмірному спустошенню депо.

Наше припущення співзвучне з гіпотезою Канцели та співавт. [26], якою постулюється наявність осциляторної одиниці, що складається з ріанодинчутливого та $І Ф_{3}$-чутливого $\mathrm{Ca}^{2+}$-каналів. Власне функціонування такої осциляторної одиниці забезпечує генерацію, на думку авторів, $\mathrm{Ca}^{2+}-$ хвиль у цитоплазмі.

Гіпотеза про об'єднання $\mathrm{Ca}^{2+}$-транспортувальних систем певної ділянки цитоплазми у $\mathrm{Ca}^{2+}$-функціональну одиницю дає змогу глибше зрозуміти механізми взаємозв'язку між цими системами. Крім того, поняття $\mathrm{Ca}^{2+}$-функціональна одиниця є значно ширшим, ніж осциляторна одиниця, оскільки його можна застосувати до набору $\mathrm{Ca}^{2+}$-транспортувальних систем будь-якої ділянки цитоплазми, у тому числі і тих, діяльність яких не пов'язана з генерацією $\mathrm{Ca}^{2+}-$ хвиль (осциляціями $\mathrm{Ca}^{2+}$ ).

Виходячи із наведених вище принципів організації ендоплазматичної $\mathrm{Ca}^{2+}$ функціональної одиниці, можна пояснити раніше отримані нами результати, трактування яких раніше викликало деякі труднощі.

По-перше, ріанодин у високих концентраціях (500 нмоль/л; рис. 2) збільшує, діючи у стані спокою (рис. $1, A$ ), вміст $\mathrm{Ca}^{2+}$ у тканині залоз унаслідок зміщення рівноваги в бік транспортування $\mathrm{Ca}^{2+}$ у люмен ендоплазматичного ретикулуму.

По-друге, додавання ріанодину до середовища інкубації у низькій концентрації (5 нмоль/л; рис. 3) спричиняє вивільнення депонованого $\mathrm{Ca}^{2+}$. Якщо викид 


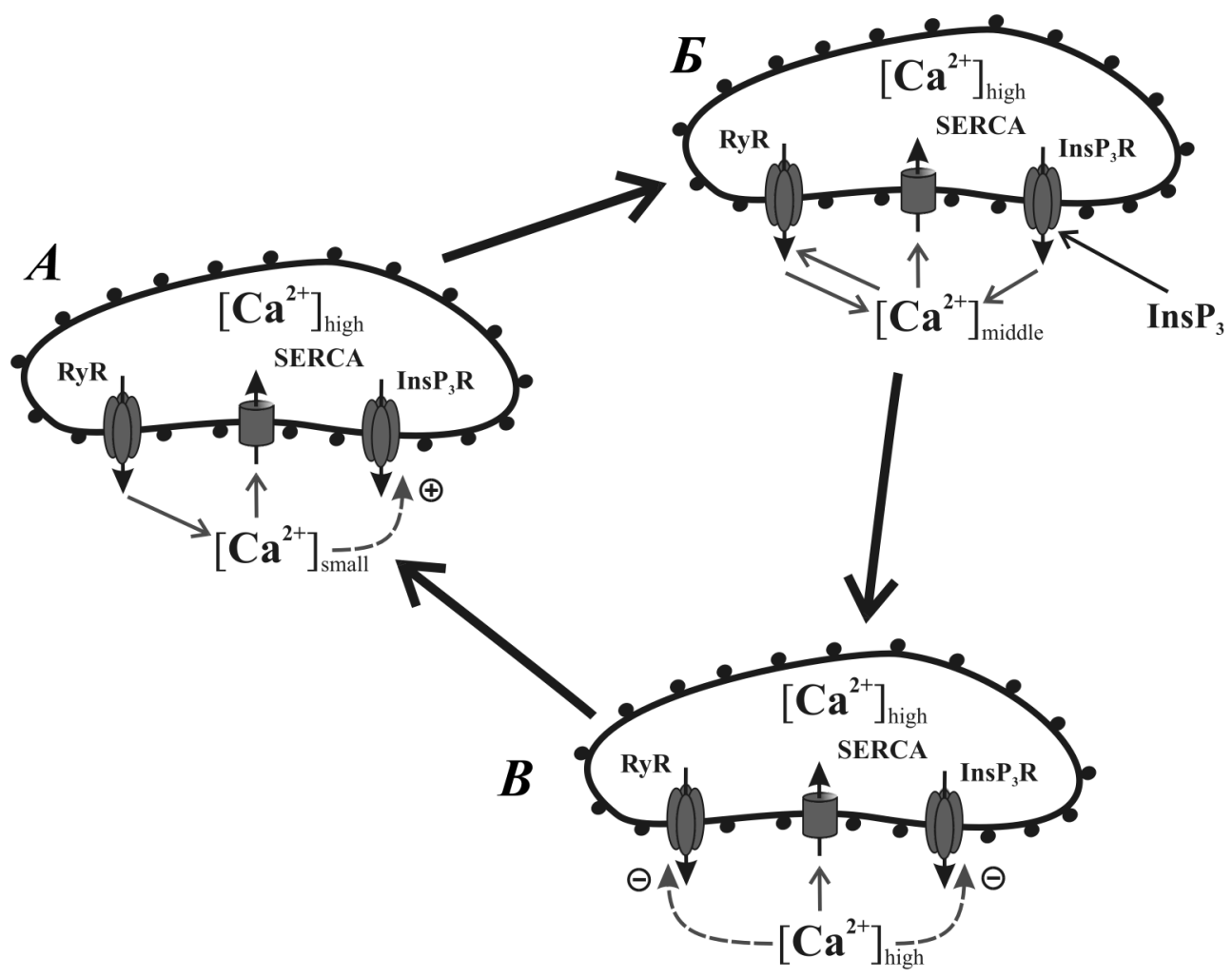

Рис. 1. Цикл активності ендоплазматичної $\mathrm{Ca}^{2+}$-функціональної одиниці секреторних клітин слинних залоз личинки Chironomus plumosus:

A - стан спокою $\mathrm{Ca}^{2+}$-функціональної одиниці, за якого підтримується висока чутливість до $Ф_{3} ;$ Б - стан активності $\mathrm{Ca}^{2+}$-функціональної одиниці, який досягається завдяки дії агоніста на $І \Phi_{3}$-чутливі $\mathrm{Ca}^{2+}$-канали і тригерній активації ріанодинчутливих $\mathrm{Ca}^{2+}$-каналів; $B$ стан інактивації $\mathrm{Ca}^{2+}$-функціональної одиниці, протягом якого рівновага зміщується в бік депонування $\mathrm{Ca}^{2+}$ і система переходить у стан спокою;

RyR - ріанодинчутливий $\mathrm{Ca}^{2+}$-канал, InsP ${ }_{3} \mathrm{R}-$ IФ $_{3}$-чутливий $\mathrm{Ca}^{2+}$-канал, SERCA - $\mathrm{Ca}^{2+}$-помпа ендоплазматичного ретикулуму; $\left[\mathrm{Ca}^{2+}\right]_{\text {small }}$, $\left[\mathrm{Ca}^{2+}\right]_{\text {middle }} \mathrm{i}\left[\mathrm{Ca}^{2+}\right]_{\text {high }}-$ низька, середня і висока цитозольна концентрація катіонів $\mathrm{Ca}^{2+} ; \operatorname{lns} \mathrm{P}_{3}-\mathrm{I \Phi}_{3}$

Fig. 1. Activity cycle of endoplasmic $\mathrm{Ca}^{2+}$-functional unit of Chironomus plumosus larvae secretory cells of salivary glands:

$A$ - resting state of $\mathrm{Ca}^{2+}$-functional unit, in which high sensitivity to $\mathrm{InSP}_{3}$ is supporting; $\overline{-}$ activated state of $\mathrm{Ca}^{2+}$-functional unit is achieved due to agonist effect to $\mathrm{InsP}_{3} \mathrm{Rs}^{2}$ and trigger activation RyRs; $B$ - inactivated state of $\mathrm{Ca}^{2+}$-functional unit, balance displacement in the side of $\mathrm{Ca}^{2+}$ deposition and as a result system pass to a resting state

$\mathrm{Ca}^{2+}$ внаслідок цього не досягає певного критичного рівня, то це супроводжується незначною активацією ІФ -чутливих $\mathrm{Ca}^{2+}$-каналів завдяки підвищенню чутливості системи до ендогенного ІФ , який, очевидно, продовжує спонтанно утворюватися за умов досліду. Як наслідок, за наявності ріанодину у середовищі інкубації гепарин, пригнічуючи ІФ -чутливі $\mathrm{Ca}^{2+}$-канали, спричиняє збільшення вмісту $\mathrm{Ca}^{2+}$ у тканині залоз (рис. 3, Б). У контрольних умовах (без ріанодину) ефект гепарину ми зареєструвати не змогли [13]. 


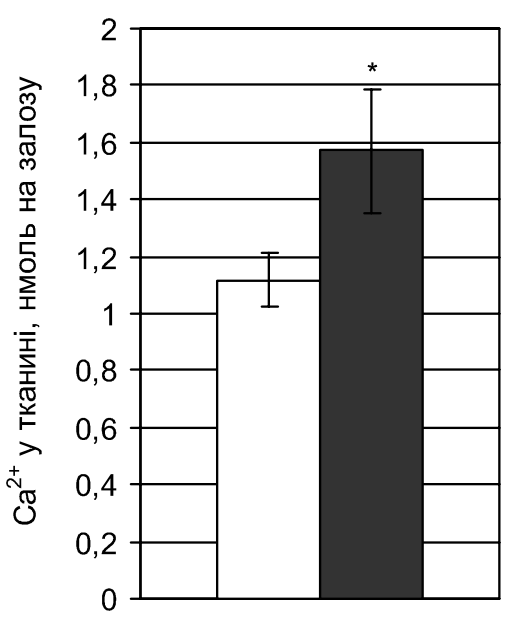

$\square$ контроль $\square$ ріанодин 500 нмоль/л

A

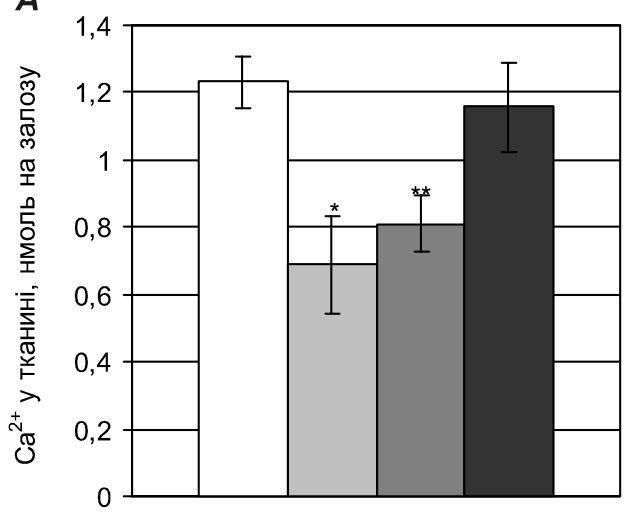

口контроль

口ріанодин $\square \mid \Phi_{3}$

$\square$ ріанодин $+1 \Phi_{3}$
Рис. 2. Зміна вмісту $\mathrm{Ca}^{2+}$ у тканині слинних залоз, оброблених сапоніном, під впливом ріанодину у концентрації 500 нмоль/л $[1,13]$ :

$\left[\mathrm{Na}^{+}\right]=15,3$ ммоль/л, $\left[\mathrm{K}^{+}\right]=129,94$ ммоль/л; * різниця порівняно з контролем достовірна з $P<0,05$, $n=7$

Fig. 2. $\mathrm{Ca}^{2+}$-content changes in tissue of salivary glands, treated with saponin, under the influence of ryanodin in concentration $500 \mathrm{nmol} / \mathrm{l}[1,13]$ :

$\left[\mathrm{Na}^{+}\right]=15.3 \mathrm{mmol} / \mathrm{l},\left[\mathrm{K}^{+}\right]=129,94 \mathrm{mmol} / \mathrm{l} ;{ }^{*}-$ difference is significant in comparison to control with $P<0.05 ; \mathrm{n}=7$

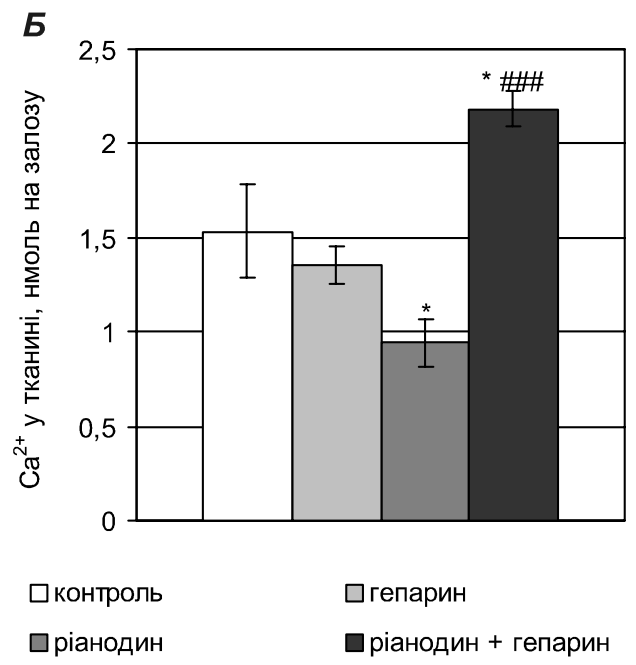

Рис. 3. Залежність функціонування $\mid \Phi_{3}$-чутливих $\mathrm{Ca}^{2+}$-каналів від стану ріанодинчутливих $\mathrm{Ca}^{2+}$-каналів [1]: зміни вмісту $\mathrm{Ca}^{2+}$ у тканині залоз, оброблених сапоніном, під впливом $I \Phi_{3}(A)$ та гепарину (Б) за відсутності і наявності ріанодину у середовищі інкубації; залози інкубували у номінально безкальцієвому середовищі; $\left[\mathrm{Na}^{+}\right]=15,3$ ммоль/л, $\left[\mathrm{K}^{+}\right]=129,94$ ммоль/л; $\left[\mathrm{I \Phi}_{3}\right]=10$ мкмоль/л, [гепарин] $=500$ мкг $/$ мл, [ріанодин] $=5$ нмоль/л; * - різниця порівняно з контролем достовірна з $P<0,05,{ }^{\star *}-$ з $P<0,01$, \#\#\# - різниця порівняно з гепаринвмісним достовірна з $P<0,001$; $\mathrm{n}=6$

Fig. 3. InsP ${ }_{3} R$ functioning dependence on RyRs state [1]:

$\mathrm{Ca}^{2+}$-content changes in tissue of salivary glands, treated with saponin, under the influence of $\operatorname{InsP}_{3}(A)$ and heparin $(E)$ at absence and presence of ryanodine in the incubatory medium; glands were treated in nominal $\mathrm{Ca}^{2+}$ free medium; $\left[\mathrm{Na}^{+}\right]=15.3 \mathrm{mmol} / \mathrm{l},\left[\mathrm{K}^{+}\right]=129.94 \mathrm{mmol} / \mathrm{l}$; $\left[\mathrm{InsP}_{3}\right]=10 \mu \mathrm{mol} / \mathrm{l}$, [heparin] $=500 \mu \mathrm{g} / \mathrm{ml}$, [ryanodin] $=5 \mathrm{nmol} / \mathrm{l}$; - difference is significant in comparison to control with $P<0.05$, ${ }^{\star *}-P<0.01, \# \# \#-$ difference is significant in comparison to heparin-containing medium with $P<0.001 ; \mathrm{n}=6$ 
I по-третє. У випадку, коли вивільнення $\mathrm{Ca}^{2+}$ з депо ріанодином у часі збігається з активацією його вивільнення екзогенним IФ ${ }_{3} \mathrm{Ca}^{2+}$-функціональна одиниця переходить у стан інактивації (рис. $1, B$ ), що, мабуть, і спостерігалося у представленому на рис. 3 , $A$ експерименті.

\section{$\mathrm{Ca}^{2+}$-функціональна одиниця плазматичної мембрани}

Метод внутрішньоклітинної перфузії дає змогу здійснювати, як вважається, повний контроль над концентраційними градієнтами іонів, що проникають через мембрану. Тим не менше, нами встановлено, що між потенціалкерованими $\mathrm{Ca}^{2+}$ каналами та $\mathrm{Na}^{+}-\mathrm{Ca}^{2+}$-обмінником плазматичної мембрани існують тісні функціональні зв'язки навіть за умов внутрішньоклітинної перфузії [5].

На рис. 4 криві 1 і 2 відображають залежність амплітуди $\mathrm{Ca}^{2+}$-струму від наявності натрієвого градієнта за різних значень фіксованого потенціалу і використання внутрішньоклітинного розчину без $\mathrm{Ca}^{2+}-\mathrm{Mg}^{2+}$-ЕГТА-буфера; криві 3 і 4 відображають цю ж залежність за внутрішньоклітиного розчину зі стабілізованою $\left[\mathrm{Ca}^{2+}\right]$ на рівні 10 мкмоль/л. Звертає на себе увагу, що за стабілізованого рівня цитозольного $\mathrm{Ca}^{2+}$ залежність амплітуди потенціалкерованого $\mathrm{Ca}^{2+}$-струму як від рівня фіксованого потенціалу, так і від концентраційного натрієвого градієнта $€$ менш вираженою. Аналізуючи ці дані, ми зробили висновок, що залежність амплітуди $\mathrm{Ca}^{2+}$-струму від наявності натрієвого градієнта зумовлена не підвищеною проникністю $\mathrm{Ca}^{2+}$-каналів для одновалентних катіонів, а залежністю їхньої провідності від функціонування $\mathrm{Na}^{+}-\mathrm{Ca}^{2+}$-обмінника [10].

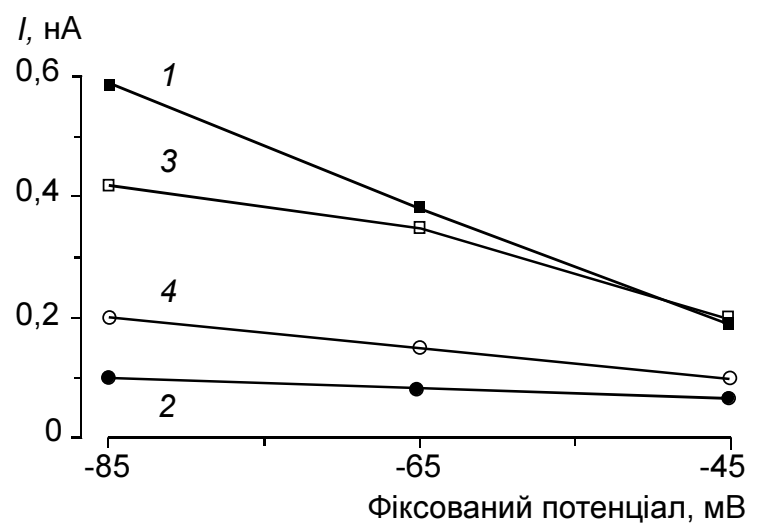

Рис. 4. Залежність амплітуди вхідного потенціалкерованого $\mathrm{Ca}^{2+}$-струму від натрієвого концентраційного градієнта за різних значень фіксованого потенціалу та $\left[\mathrm{Ca}^{2+}\right]$ у цитозолі $[5,7]$ : $\left[\mathrm{Na}^{+}\right]_{\mathrm{e}}=136,9$ (криві 1 і 3) або 16 (криві 2 і 4) ммоль/л, $\left[\mathrm{Ca}^{2+}\right]_{\mathrm{e}}=1,76$ ммоль/л, $\left[\mathrm{Na}^{+}\right]_{\mathrm{i}}=16$ ммоль/л; $\left[\mathrm{Ca}^{2+}\right]_{\mathrm{i}}=10$ мкмоль/л (криві 3 і 4; $\mathrm{Ca}^{2+}-\mathrm{Mg}^{2+}$-ЕГТА-буфер) або не задавали (криві 1 і 2); фіксований потенціал -85 , -65 або -45 мB, тестований - -25 мB; $n=6$

Fig. 4. Inward voltage-dependent $\mathrm{Ca}^{2+}$-current dependence on sodium concentration gradient in difference values of holding potential and $\left[\mathrm{Ca}^{2+}\right]$ in cytosol $[5,7]$ :

$\left[\mathrm{Na}^{+}\right]_{\mathrm{e}}=136.9$ (curves 1 and 3) or 16 (curves 2 and 4) mmol/l, $\left[\mathrm{Ca}^{2+}\right]_{\mathrm{e}}=1,76 \mathrm{mmol} / \mathrm{l},\left[\mathrm{Na}^{+}\right]_{\mathrm{i}}=16 \mathrm{mmol} / \mathrm{l}$; $\left[\mathrm{Ca}^{2+}\right]_{\mathrm{i}}=10 \mu \mathrm{mol} / \mathrm{l}$ (curves 3 and 4 ; $\mathrm{Ca}^{2+}-\mathrm{Mg}^{2+}$-EGTA-buffer) or nominal $\mathrm{Ca}^{2+}$ free solution (curves 1 and 2); holding potential -85 , -65 or $-45 \mathrm{mV}$, tested potential $--25 \mathrm{mV} ; \mathrm{n}=6$

Встановлено також [15], що внаслідок додавання до внутрішньоклітинного розчину блокатора $\mathrm{Ca}^{2+}$-помпи еозину $\mathrm{Y}$ амплітуда вхідного струму $\mathrm{Na}^{+}-\mathrm{Ca}^{2+}$-обміну 
дещо збільшувалася (рис. 5, A). Аналогічно діє й інший блокатор $\mathrm{Ca}^{2+}$-помпи ортованадат у концентрації 10 мкмоль/л, стимулюючий ефект якого, правда, зменшувався за концентрації 100 мкмоль/л. Відомо, що еозин Үє досить-таки специфічним інгібітором $\mathrm{Mg}^{2+}$, АТФ-залежних систем активного транспортування $\mathrm{Ca}^{2+}$ та не пригнічує $\mathrm{Na}^{+}-\mathrm{Ca}^{2+}$-обмінник [21]. Тим більше, він не може активувати функціонування обмінника. Тому збільшення амплітуди вхідного струму $\mathrm{Na}^{+}-\mathrm{Ca}^{2+}$-обміну (катіони $\mathrm{Ca}^{2+}$ зв'язуються 3 внутрішньоклітинного боку плазматичної мембрани) зумовлене пригніченням $\mathrm{Ca}^{2+}$-помпи плазматичної мембрани (i, відповідно, збільшення $\left[\mathrm{Ca}^{2+}\right]_{i}$ у внутрішньоклітинному примембранному просторі).

А введення в клітину АТФ на фоні 1 ммоль/л GSH супроводжується зменшенням амплітуди вхідного струму $\mathrm{Na}^{+}-\mathrm{Ca}^{2+}$-обміну (рис. 5, Б). Причиною зменшення струму у цьому випадку $є$, на нашу думку, стимуляція надлишком АТФ функціонування $\mathrm{Ca}^{2+}$-помпи плазматичної мембрани, оскільки порушення акумулювання $\mathrm{Ca}^{2+}$ у мітохондріях чи вивільнення його з депо не впливало на амплітуду струму $\mathrm{Na}^{+}-$ $\mathrm{Ca}^{2+}$-обміну. Цілком можливо, що це зумовлено особливостями локалізації цих $\mathrm{Ca}^{2+}$-транспортувальних систем чи органел, які їх містять. Стимулювання $\mathrm{Ca}^{2+}$ помпи призводить до зменшення $\left[\mathrm{Ca}^{2+}\right]$ у цитозолі і, відтак, до пригнічення функціонування $\mathrm{Na}^{+}-\mathrm{Ca}^{2+}-$-обмінника.

Отже, тісні функціональні зв'язки існують і між $\mathrm{Na}^{+}-\mathrm{Ca}^{2+}$-обмінником та $\mathrm{Ca}^{2+}-$ помпою плазматичної мембрани. Тому ми маємо підстави говорити про наявність $\mathrm{Ca}^{2+}$-функціональної одиниці плазматичної мембрани. На відміну від вищеописаної ендоплазматичної $\mathrm{Ca}^{2+}$-функціональної одиниці, катіони $\mathrm{Ca}^{2+}$ у цьому

$A$

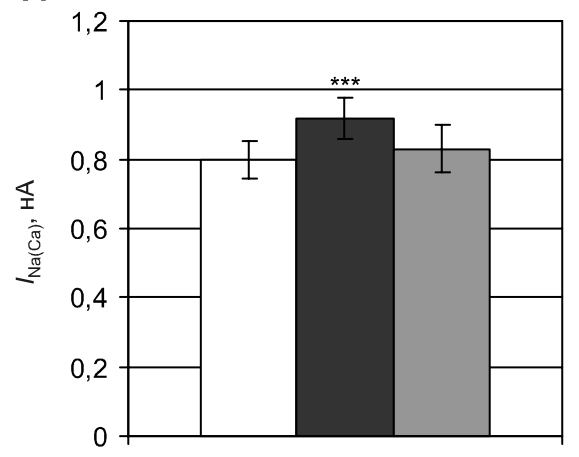

$\square$ контроль $\square$ еозин Ү $\square$ відмивання
Б

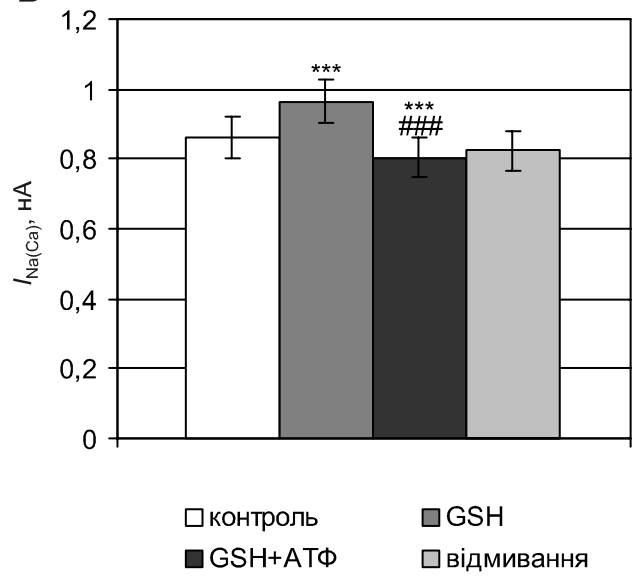

Рис. 5. Зміна амплітуди вхідного струму $\mathrm{Na}^{+}-\mathrm{Ca}^{2+}$-обміну внаслідок блокування $\mathrm{Ca}^{2+}$-помпи еозином Y $(A)$ та їі стимулювання аденозинтрифосфатом за наявності у середовищі відновленого глутатіону (Б) [15]:

$\left[\mathrm{Na}^{+}\right]_{\mathrm{e}}=136,9$ ммоль/л, $\left[\mathrm{Ca}^{2+}\right]_{\mathrm{e}}=1,76$ ммоль/л, $\left[\mathrm{Na}^{+}\right]_{\mathrm{i}}=16$ ммоль/л; [еозин Y $]_{\mathrm{e}}=10$ мкмоль/л; $\left.[\mathrm{GSH}]_{\mathrm{i}}=1 \mathrm{ммоль/л,} \mathrm{[АТФ]}\right]_{\mathrm{i}}=1$ ммоль/л; фіксований потенціал $-20 \mathrm{MB}$, тестований - -60 мВ; ***

і \#\#\# - зміна достовірна відповідно відносно контролю та відносно GSH з $P<0,001 ; n=6$ і 10

Fig. 5. Inward current amplitude change of $\mathrm{Na}^{+}-\mathrm{Ca}^{2+}$ exchange as a result of $\mathrm{Ca}^{2+}$-pump inhibition with eosin $Y(A)$ and its stimulation with ATP in presence reduced glutathione (Б) [15]:

$\left[\mathrm{Na}^{+}\right]_{\mathrm{e}}=136.9 \mathrm{mmol} / \mathrm{l},\left[\mathrm{Ca}^{2+}\right]_{\mathrm{e}}=1.76 \mathrm{mmol} / \mathrm{l},\left[\mathrm{Na}^{+}\right]_{\mathrm{i}}=16 \mathrm{mmol} / \mathrm{l} ;[\mathrm{eosin} \mathrm{Y}]_{\mathrm{e}}=10 \mu \mathrm{mol} / \mathrm{l} ;$ $[\mathrm{GSH}]_{\mathrm{i}}=1 \mathrm{mmol} / \mathrm{l},[\mathrm{AT} \Phi]_{\mathrm{i}}=1 \mathrm{mmol} / \mathrm{l}$; holding potential $-20 \mathrm{mV}$, tested potential $-60 \mathrm{mV}$; ${ }^{* \star \star}$ and \#\#\#- difference is significant in comparison to control and GSH with $P<0.001 ; \mathrm{n}=6$ and 10 
випадку не депонуються в обмеженому просторі, а виводяться у позаклітинне середовище. Але для розуміння значення цієї $\mathrm{Ca}^{2+}$-функціональної одиниці принципового значення це не має.

До певної міри стан $\mathrm{Ca}^{2+}$-функціональної одиниці плазматичної мембрани визначається залежністю $\mathrm{Na}^{+}-\mathrm{Ca}^{2+}$-обміну від активності $\mathrm{Na}^{+}-\mathrm{K}^{+}$-помпи: наявність у середовищі уабаїну дещо нівелювало ефект збільшення позаклітинної чи внутрішньоклітинної концентрації $\mathrm{K}^{+}$(рис. 6), а також підсилювало ефект зменшення позаклітинної концентрації $\mathrm{Na}^{+}$на амплітуду вхідного струму $\mathrm{Na}^{+}-\mathrm{Ca}^{2+}$-обміну [19].
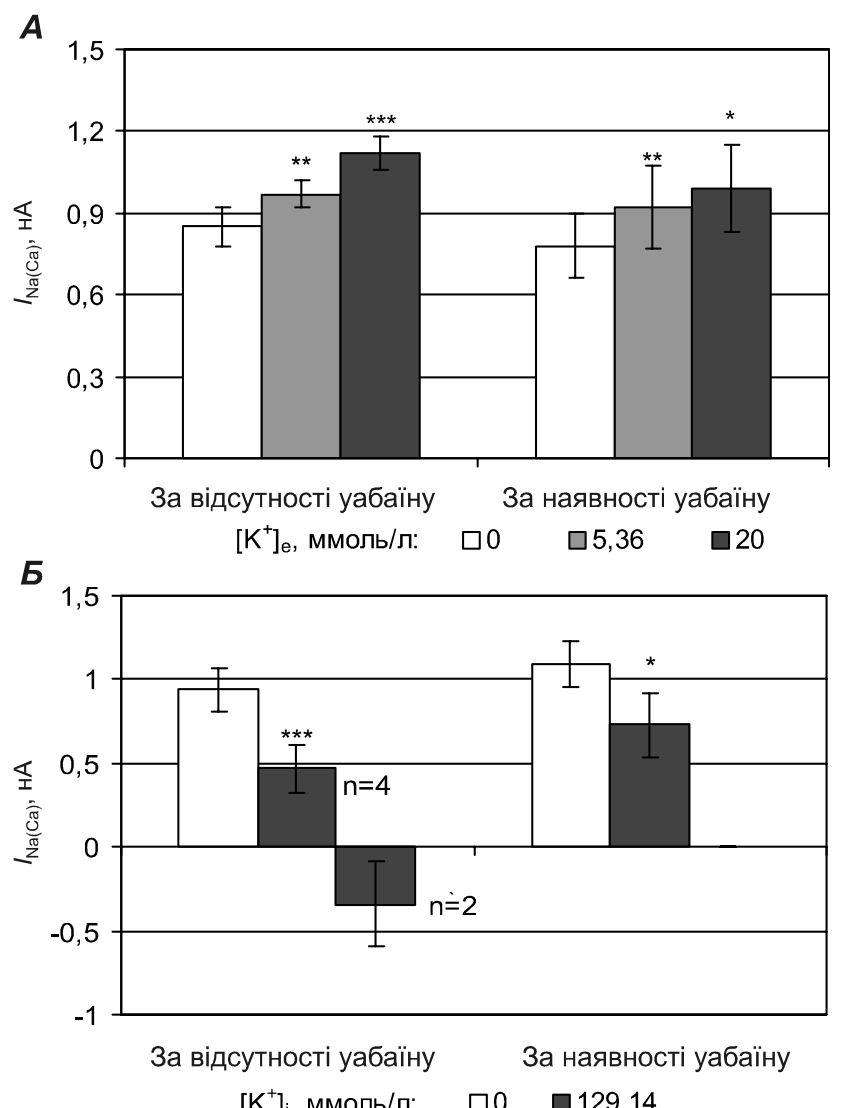

$\left[\mathrm{K}^{+}\right]_{\mathrm{i}}$, ммоль/л: $\quad \square 0 \quad \square 129,14$

Рис. 6. Залежність амплітуди вхідного струму $\mathrm{Na}^{+}-\mathrm{Ca}^{2+}$-обміну від позаклітинної $(A)$ і внутрішньоклітинної (Б) $\left[\mathrm{K}^{+}\right]$за наявності і відсутності уабаїну в середовищі [19]: негативні значення амплітуди - вхідний напрям струму, позитивні - вихідний напрям; $\left[\mathrm{Na}^{+}\right]_{\mathrm{e}}=120 \mathrm{ммоль/л,}$ $\left[\mathrm{Ca}^{2+}\right]_{\mathrm{e}}=1,76$ ммоль/л, $\left[\mathrm{Na}^{+}\right]_{\mathrm{i}}=16$ ммоль/л; $\left[\mathrm{K}^{+}\right]_{\mathrm{i}}=0$ ммоль/л $(A),\left[\mathrm{K}^{+}\right]_{\mathrm{e}}=5,36 \mathrm{ммоль/л}(Б) ;$ [уабаїн] = 25 мкмоль/л; фіксований потенціал -20 мВ, тестований - -60 мВ; за контроль прийнято амплітуду струму за відсутності $\mathrm{K}^{+}$у середовищі; * - зміна достовірна відносно контролю з $P<0,05 ;{ }^{\star \star}-3 P<0,01 ;{ }^{* \star}-3 P<0,001 ; \mathrm{n}=7$ i 6

Fig. 6. Inward current amplitude dependence of $\mathrm{Na}^{+}-\mathrm{Ca}^{2+}$ exchange on extracellular $(A)$ and intracellular (Б) $\left[\mathrm{K}^{+}\right]$in presence and absence ouabain in medium [19]:

negative amplitude values - inward current, positive - outward current; $\left[\mathrm{Na}^{+}\right]_{\mathrm{e}}=120 \mathrm{mmol} / \mathrm{l}$, $\left[\mathrm{Ca}^{2+}\right]_{\mathrm{e}}=1.76 \mathrm{mmol} / \mathrm{l},\left[\mathrm{Na}^{+}\right]_{\mathrm{i}}=16 \mathrm{mmol} / \mathrm{l} ;\left[\mathrm{K}^{+}\right]_{\mathrm{i}}=0 \mathrm{mmol} / \mathrm{l}(A),\left[\mathrm{K}^{+}\right]_{\mathrm{e}}=5.36 \mathrm{mmol} / \mathrm{l}(\bar{L})$; [ouabain] $=25 \mu \mathrm{mol} / \mathrm{l}$; holding potential $-20 \mathrm{mV}$, testing potential $-60 \mathrm{mV}$; current amplitude in absence of $\mathrm{K}^{+}$was taken as a control; ${ }^{\star}$ - difference is significant in comparison to control with $P<0.05 ;{ }^{\star \star}$ - with $P<0.01 ;{ }^{\star \star \star}-$ with $P<0.001 ; \mathrm{n}=7$ and 6 
Очевидно, така організація взаємовідносин між $\mathrm{Ca}^{2+}$-транспортувальними системами плазматичної мембрани відіграє важливу роль для генерування фізіологічного $\mathrm{Ca}^{2+}$-сигналу у базальному кальцієвому домені - примембранному просторі базальної (базо-латеральної) частини секреторних клітин слинних залоз личинки Chironomus plumosus, відокремленому [2] від іншої частини цитоплазми надзвичайно щільним шаром мітохондрій.

Характерною ознакою $\mathrm{Ca}^{2+}$-функціональної одиниці плазматичної мембрани $\epsilon$ їі залежність від рівня мембранного потенціалу, а не лише від цитозольної $\left[\mathrm{Ca}^{2+}\right.$. Власне деполяризація плазматичної мембрани внаслідок активації молекулою АТФ P2X-рецепторів спричиняє перехід цієї $\mathrm{Ca}^{2+}$-функціональної одиниці у стан активності, що досягається активацією потенціалкерованих $\mathrm{Ca}^{2+}$-каналів. Такий висновок можна зробити, якщо, звичайно, не включати P2X-рецептори до складу $\mathrm{Ca}^{2+}$-функціональної одиниці плазматичної мембрани (у нас немає експериментальних даних, які б свідчили, що Р2Х-рецептори входять до складу цієї одиниці, хоча повністю відкидати таку можливість не можна).

Обмеження надходження $\mathrm{Ca}^{2+}$ у цитозоль (інактивація $\mathbf{C a}^{2+}$-функціональної одиниці) теж реалізується не лише збільшенням цитозольної $\mathrm{Ca}^{2+}$, а й подальшою деполяризацією плазматичної мембрани, тобто внаслідок не лише $\mathrm{Ca}^{2+}$-залежної, а й потенціалозалежної інактивації $\mathrm{Ca}^{2+}$-каналів. Крім того, деполяризація мембрани має часове обмеження для розвитку кальцієвої відповіді ще й за рахунок активації високопорогових потенціалкерованих $\mathrm{K}^{+}-\mathrm{i} \mathrm{Cl}-$-каналів. Гіперполяризація мембрани, що виникає внаслідок виходу катіонів $\mathrm{K}^{+}$потенціалкерованими $\mathrm{K}^{+}-$ каналами (калієвий електрохімічний градієнт спрямований з клітини) та входу аніонів $\mathrm{Cl}^{-}$потенціалкерованими $\mathrm{Cl}^{-}$-каналами (хлорний електрохімічний градієнт спрямований у клітину), обмежує в часі можливість $\mathrm{Na}^{+}-\mathrm{Ca}^{2+}$-обмінника транспортувати $\mathrm{Ca}^{2+}$ у клітину. Тому головне значення $\mathrm{Na}^{+}-\mathrm{Ca}^{2+}$-обмінника, як і $\mathrm{Ca}^{2+}$-помпи плазматичної мембрани, є виведення $\mathrm{Ca}^{2+}$ у позаклітинне середовище $\mathrm{i}$, тим самим, переведення $\mathrm{Ca}^{2+}$-функціональної одиниці плазматичної мембрани у стан спокою.

\section{Ендоплазматично-мітохондріальна $\mathrm{Ca}^{2+}$-функціональна одиниця}

У секреторних клітинах слинних залоз личинки Chironomus plumosus можна виділити ще одну, ендоплазматично-мітохондріальну Са ${ }^{2+}$-функціональну одиницю, яка складається з каналів вивільнення $\mathrm{Ca}^{2+}$ ендоплазматичного ретикулуму та $\mathrm{Ca}^{2+}$-уніпортера мітохондрій.

Базується цей висновок, перш за все, на тому, що ефекти ріанодину в активуючій ріанодинчутливі $\mathrm{Ca}^{2+}$-канали та рутенію червоного за умови поєднання їх у середовищі інкубації мають неадитивний характер (рис. 7, A) [2]. Слід зазначити, що ефекти цих речовин повинні бути адитивними, якщо функціонування $\mathrm{Ca}^{2+}$-активованих $\mathrm{Ca}^{2+}$-каналів ендоплазматичного ретикулуму і $\mathrm{Ca}^{2+}$-уніпортера мітохондрій не залежить одне від одного.

Виявлений ефект підтверджує модифікуючу дію мітохондрій на ріанодиніндуковане вивільнення $\mathrm{Ca}^{2+} 3$ ендоплазматичного ретикулуму. Відомо також, що рутеній червоний може пригнічувати вивільнення $\mathrm{Ca}^{2+}$ ріанодинчутливими $\mathrm{Ca}^{2+}$ каналами [24]. Але у встановленому нами випадку такий механізм $є$ неможливим, оскільки тоді рутеній червоний повністю запобігав би вивільненню $\mathrm{Ca}^{2+} 3$ ендоплазматичного ретикулуму під впливом ріанодину. 
A

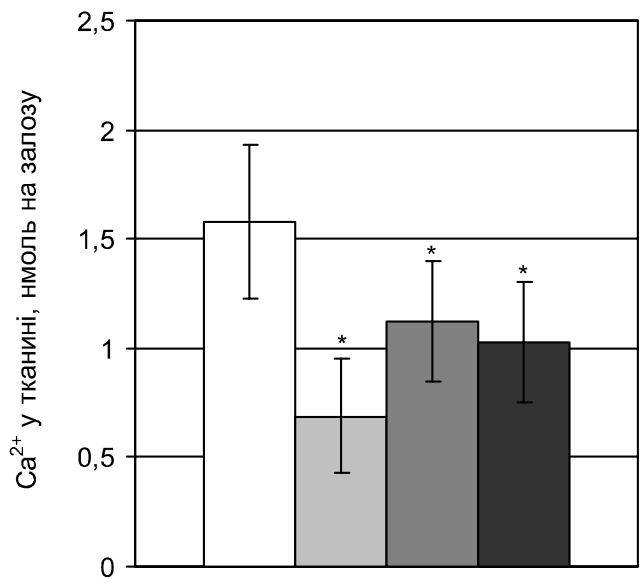

$\square$ контроль

口рутеній $\square$ ріанодин

$\square$ рутеній + ріанодин
Б

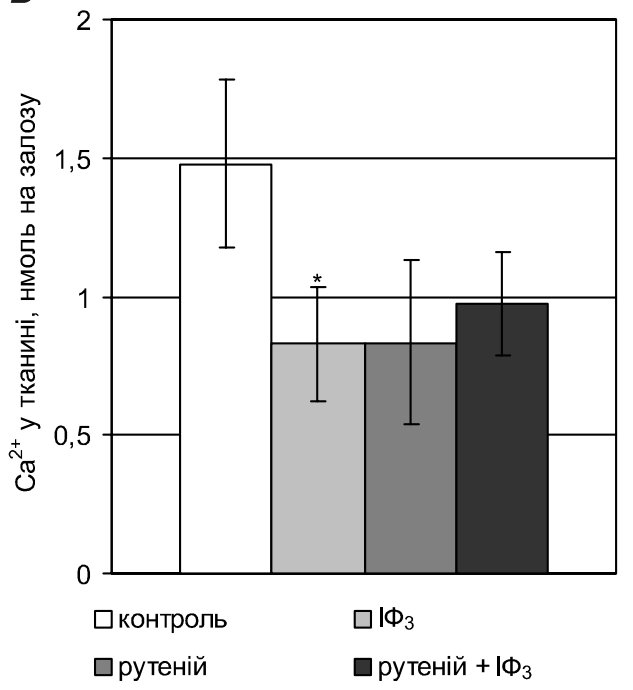

Рис. 7. Зміни вмісту $\mathrm{Ca}^{2+}$ у тканині слинних залоз, оброблених сапоніном, за одночасної дії ріанодину та рутенію червоного $(A)$ й інозитолтрифосфату та рутенію червоного (Б) відповідно [2]: $\left[\mathrm{Na}^{+}\right]=15,3$ ммоль/л, $\left[\mathrm{K}^{+}\right]=129,94$ ммоль/л; [рутеній червоний] $=10$ мкмоль/л, [ріанодин] $=5$ нмоль/л; $\left[\Phi_{3}\right]=10$ мкмоль/л; * - різниця порівняно 3 контролем статистично достовірна з $P<0,05 ; \mathrm{n}=6$ i 7

Fig. 7. Changes of $\mathrm{Ca}^{2+}$ content in tissue of salivary glands treated with saponin, simultaneous action of ryanodine and ruthenium red $(A)$ or $\operatorname{InsP}_{3}$ and ruthenium red $(B)$ respectively [2]:

$\left[\mathrm{Na}^{+}\right]=15.3 \mathrm{mmol} / \mathrm{l},\left[\mathrm{K}^{+}\right]=129.94 \mathrm{mmol} / \mathrm{l}$; [ruthenium red] $=10 \mu \mathrm{mol} / \mathrm{l}$, [ryanodine] $=5 \mathrm{nmol} / \mathrm{l}$; $\left[\right.$ InsP $\left._{3}\right]=10 \mu \mathrm{mol} / \mathrm{l} ;{ }^{*}$ - difference is significant in comparison to control with $P<0.05 ; \mathrm{n}=6$ and 7

По-друге, за стимуляції $І \Phi_{3}$-чутливих $\mathrm{Ca}^{2+}$-каналів додаванням до середовища інкубації IФ ${ }_{3}$ та за одночасного пригнічення функціонування $\mathrm{Ca}^{2+}$-уніпортера мітохондрій рутенієм червоним (рис. 7, Б) не спостерігалося статистично достовірних змін вмісту $\mathrm{Ca}^{2+}$ у тканині залоз, оброблених сапоніном, порівняно з контролем (середовище, яке не містило ні рутенію червоного, ні I $\Phi_{3}$ ). Хоча застосування $І \Phi_{3}$ викликало статистично достовірне зменшення вмісту $\mathrm{Ca}^{2+}$ у тканині залоз, оброблених сапоніном, на $43,78 \pm 11,82 \%(P=0,042, \mathrm{n}=7)$ відносно контролю, і цей ефект неодноразово підтверджувався нами у попередніх експериментах. Таким чином, блокування рутенієм червоним процесу акумуляції $\mathrm{Ca}^{2+}$ мітохондріями запобігає активуванню вивільнення $\mathrm{Ca}^{2+}$ з $1 \Phi_{3}$-чутливого депо.

У досліджуваних клітинах $\mathrm{Ca}^{2+}$-уніпортер перебуває, мабуть, у стані динамічної рівноваги з розміщеними поруч каналами вивільнення $\mathrm{Ca}^{2+}$ з депо, і за відсутності стимуляції між цими структурами відбувається обмін іонами $\mathrm{Ca}^{2+}$. Ці системи транспортування $\mathrm{Ca}^{2+}$ і формують ендоплазматично-мітохондріальну $\mathrm{Ca}^{2+}$-функціональну одиницю, яка належить до II типу. У стані спокою внутрішньоклітинні $\mathrm{Ca}^{2+}$-канали вивільняють певну кількість $\mathrm{Ca}^{2+}$, які транспортуються не тільки помпою назад у люмен ендоплазматичного ретикулуму, а й уніпортером у матрикс мітохондрій, тому не відбувається генерація клітинної відповіді. Заблокувавши уніпортер мітохондрій, ми спричинили, очевидно, локальне підвищення $\left[\mathrm{Ca}^{2+}\right]$ 
поруч розташованого ІФ -чутливого депо. Відомо, що на ІФ -чутливому рецепторі наявні інгібіторні й активуючі сайти зв'язування $\mathrm{Ca}^{2+}[22,25]$. Відбувається, ймовірно, швидке зв'язування $\mathrm{Ca}^{2+} 3$ інгібіторними сайтами $Ф_{3}$-чутливих $\mathrm{Ca}^{2+}-$ каналів. Це призводить до пригнічення, за принципом негативного зворотного зв'язку, подальшого вивільнення $\mathrm{Ca}^{2+}$ з депо. Тому одночасне застосування IФ та рутенію червоного не викликає зменшення вмісту $\mathrm{Ca}^{2+}$ у тканині залоз.

Оскільки функціонування ріанодинчутливих $\mathrm{Ca}^{2+}$-каналів теж залежить від $\left[\mathrm{Ca}^{2+}\right]$ у цитозолі [41], то, аналогічно, за одночасної дії ріанодину та рутенію червоного зменшення вмісту $\mathrm{Ca}^{2+}$ у тканині залоз $€$ менш вираженим, ніж за дії одного лише ріанодину. Можна припустити також, зважаючи на взаємозв'язок між вивільненням катіонів $\mathrm{Ca}^{2+} \Phi_{3}$-чутливими та ріанодинчутливими каналами (рис. 3), що пригнічення ІФ його вивільнення з ріанодинчутливого депо. Для активації ріанодинчутливого депо необхідно, щоб $І Ф_{3}-4 у т л и в і ~ \mathrm{Ca}^{2+}$-канали не були ані заблокованими, ані активованими.

Про чутливість мітохондрій до вивільнення $\mathrm{Ca}^{2+}$ з ІФ -чутливого і ріанодинчутливого депо $\mathrm{Ca}^{2+}$ існує достатньо даних, отриманих на різних клітинах, у тому числі секреторних: мітохондрії регулюють спряження $\mathrm{Ca}^{2+}-$ екзоцитоз у хромафінних клітинах [28], у пермеабілізованих клітинах слинних залоз м'ясної мухи вони здійснюють негативний контроль над частотою ІФ -індукованих осциляцій $\mathrm{Ca}^{2+}$, визначають тривалість міжспайкового інтервалу і, таким чином, перекодовують стимул, що модулюється амплітудою вивільнення ІФ , у частоту цитозольних осциляцій $\mathrm{Ca}^{2+}$ [40]. Взаємодія між внутрішньоклітинними каналами вивільнення $\mathrm{Ca}^{2+}$ та мітохондріями має відмінне значення залежно від розміщення самих мітохондрій у клітині. Таким чином мітохондрії здійснюють комплексний вплив на регулювання $\mathrm{Ca}^{2+}$-сигналів у секреторних клітинах.

\section{пІдсумок}

Загальноприйняте положення, що цитозольний рівень $\mathrm{Ca}^{2+}$ визначається його потоками через плазматичну мембрану і мембрану ендоплазматичного ретикулуму, на сьогодні $€$ недостатнім. Спричинило цю недостатність відкриття: а) локальних $\mathrm{Ca}^{2+}-$ хвиль [39] і б) локальних кальцієвих мікродоменів [23, 34, але див. 38], виникнення яких неможливо пояснити, виходячи із „макроцитозольної” позиції.

Локальні $\mathrm{Ca}^{2+}$-хвилі - це обмежені у просторі та часі повторювані підвищення цитозольної [ $\mathrm{Ca}^{2+}$. Найпростіші локальні $\mathrm{Ca}^{2+}$-сигнали $є$ двох типів: $\mathrm{Ca}^{2+}$ спарки (sparks), які зумовлені активацією лише ріанодинових $\mathrm{Ca}^{2+}$-каналів, наприклад, у кардіоміоцитах [27], і Са ${ }^{2+}$-пафи (puffs), зокрема, в ооцитах шпорцевої жаби [39], які спричинені активацією лише ІФ -чутливих $\mathrm{Ca}^{2+}$ каналів. Інший приклад локального $\mathrm{Ca}^{2+}$-сигналу характерний для апікального полюса секреторних клітин, наприклад, екзокринних клітин підшлункової залози [37]. Тут він характеризується повільнішим часом наростання амплітуди (>1 с) і значнішим поширенням, до 10 мкм [31], що відрізняє їх від „класичних” Са ${ }^{2+}$-пафів. За певних умов $\mathrm{Ca}^{2+}$-хвиля, яка виникла на апікальному полюсі секреторної клітини, поширюється до базального полюса - локальний $\mathrm{Ca}^{2+}$-сигнал перетворюється на 
глобальний. Але для того, щоб таке перетворення відбулося, потрібне не лише узгоджене функціонування ІФ -чутливих і ріанодинчутливих $\mathrm{Ca}^{2+}$-каналів ендоплазматичного ретикулуму - $\mathrm{Ca}^{2+}$-хвиля повинна подолати кордон із мітохондрій [35]. Встановлено також, що мітохондрії модулюють вивільнення $\mathrm{Ca}^{2+}$ з ендоплазматичного ретикулуму, запобігаючи його позитивному зворотному впливу на $І Ф_{3}$-чутливі $\mathrm{Ca}^{2+}$-канали [29], і така взаємодія можлива лише за рахунок близького розташування цих двох органел [38]. Показана і важлива роль периферичних примембранних мітохондрій у депокерованому вході $\mathrm{Ca}^{2+}$ у клітину $[32,35,36]$.

Отже, навіть такий поверховий огляд дає змогу зробити висновок, що генерування $\mathrm{Ca}^{2+}$-хвиль $€$ неможливим без узгодженості функціонування різних $\mathrm{Ca}^{2+}-$ транспортувальних систем, які належать різним клітинним мембранам. $\mathrm{Ca}^{2+}-$ транспортувальні системи не дублюють одні одних, їхнє функціонування $є$ взаємодоповнюючим. Крім того, функціонування різних $\mathrm{Ca}^{2+}$-транспортувальних систем є взаємозалежним за рахунок позитивних прямих і негативних зворотних зв'язків між ними. Ці зв'язки значною мірою реалізуються через зміну локальної $\left[\mathrm{Ca}^{2+}\right.$ біля устя $\mathrm{Ca}^{2+}$-каналу (локальних кальцієвих мікродоменів), оскільки функціонування багатьох $\mathrm{Ca}^{2+}$-транспортувальних систем також $€ \mathrm{Ca}^{2+}$-залежним процесом. Але загальної (уніфікованої) теорії, яка б задовільно пояснила роль узгодженості функціонування різних $\mathrm{Ca}^{2+}$-транспортувальних систем у $\mathrm{Ca}^{2+}$-сигналізації, на сьогодні немає. Тому як робочу гіпотезу ми пропонуємо концепцію Са ${ }^{2+}$-функціональних одиниць.

Оскільки прямі та зворотні зв'язки між $\mathrm{Ca}^{2+}$-транспортувальними системами $€$ обмежені в просторі та часі, ми дійшли висновку, що у клітині формуються цілі їхні ансамблі - $\boldsymbol{C a}^{2+}$-функціональні одиниці, з принципово новими властивостями і новими функціями, виконати які неможливо, якщо виходити з властивостей окремих їхніх складових частин. Обов'язковою умовою формування $\mathrm{Ca}^{2+}$-функціональні одиниці є входження до їі складу системи пасивного і системи активного транспортування $\mathrm{Ca}^{2+}$ та мембрани, що забезпечує компартменталізацію цих катіонів. Одні і ті ж самі транспортувальні системи (і мембрани) можуть входити до складу різних $\mathrm{Ca}^{2+}$-функціональних систем, що визначається особливостями певної клітини та доцільністю для процесів, які відбуваються у їі різних частинах. Власне на цьому етапі організації $\mathrm{Ca}^{2+}$-сигналізації виникають такі властивості, притаманні функціонуванню $\mathrm{Ca}^{2+}$-транспортувальних систем, як нестатичність (динамічність), неадитивність, висока чутливість до агоністів, самопідсилення, самообмеження у часі тощо.

Лише виходячи із таких позицій, можна пояснити ті експериментальним чином встановлені факти, які важко було пояснити в рамках панівної парадигми. Це стосується і особливостей функціонування певної $\mathrm{Ca}^{2+}$-транспортувальної

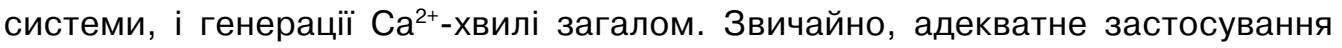
концепції для трактування особливостей $\mathrm{Ca}^{2+}$-сигналізації (чи розвиток цієї концепції) можливе після проведення досліджень з використанням реєстрації цитозольної $\left[\mathrm{Ca}^{2+}\right]$ за допомогою $\mathrm{Ca}^{2+}$-чутливих флуоресцентних зондів.

Цілком можливо, що із встановленням нових експериментальних даних запропонована концепція буде трансформуватися. Зокрема це стосується залежності функціонування $\mathrm{Ca}^{2+}$-транспортувальних систем від активності інших іонтранспортувальних систем. Особливо актуальною є проблема виявлення 
чинника, який забезпечує прямий і зворотний зв'язок між окремими складовими частинами $\mathrm{Ca}^{2+}$-функціональної одиниці, оскільки не завжди його вдається коректно ідентифікувати (досить показовим у цьому аспекті $є$ проблема узгодженості активації потенціалкерованих і ріанодинчутливих $\mathrm{Ca}^{2+}$-каналів у кардіоміоцитах [30]). Таким чинником для $\mathrm{Ca}^{2+}$-функціональної одиниці плазматичної мембрани може бути зміна мембранного потенціалу. В інших випадках цю роль можуть виконувати, на нашу думку, $\mathrm{Ca}^{2+}$-сигнальні білки [див. 33].

1. Бичкова С.В., Манько В.В. Ріанодиніндуковане вивільнення $\mathrm{Ca}^{2+}$ у секреторних клітинах слинних залоз личинки Chironomus plumosus L. Вісн. Львів. ун-ту. Сер. біол, 2004; 35: 244-250.

2. Бичкова С., Манько В., Клевець М., Кулачковський О. Роль мітохондрій у Са ${ }^{2+}$-сигналізації секреторних клітин травних залоз. Вісн. Львів. ун-ту. Сер. біол, 2007; 44: 3-14.

3. Деркач М.П., Гумецький Р.Я., Чабан М.Є. Курс варіаційної статистики. Київ: Вища школа, 1977. 206 с.

4. Клевець М.Ю., Манько В.В. Характеристика потенціалозалежного кальцієвого струму мембрани секреторних клітин. Физиол. журнал, 1992; 38(3): 70-75.

5. Клевець М.Ю., Манько В.В. Вивчення натрієвого градієнта для реєстрації струму через кальцієві потенціалозалежні канали мембрани секреторних клітин. XIV з'їзд Українського фізіологічного товариства: Тези доп. Київ, 1994: 10-11.

6. Клевець М.Ю., Манько В.В., Федірко Н.В. Дослідження нагромадження кальцію секреторними клітинами ізольованих слинних залоз личинки хірономуса та його значення для секреторного процесу (Львів. ун-т). Львів, 1996. 22 с. Укр. Деп. в Укр. IHTEI 29.10.96, № 87 - Ук 96.

7. Клевець М.Ю., Манько В.В., Федірко Н.В. та ін. Кальцій і плазматична мембрана секреторних клітин екзокринних залоз. Вісн. Київ. ун-ту. Фізіологія: Проблеми регуляції фізіологічних функцій, 2000; 6: 9-13.

8. Король T., Манько В., Клевець М. Вплив блокаторів потенціалозалежних кальцієвих каналів на стимульований гіперкалієвою деполяризацією вхід $\mathrm{Ca}^{2+}$ у клітини екзокринних залоз та їх секреторну відповідь. Галицький лікарський вісник, 1998; 5(3): 46-48.

9. Король Т.В., Манько В.В., Клевець М.Ю. Дослідження активного транспорту $\mathrm{Ca}^{2+}$ у секреторних клітинах слинних залоз личинки Chironomus plumosus L. Біологія тварин, 2000; 2(1): 92-97.

10. Манько В.В. Характеристика струмів потенціалозалежних кальцієвих каналів мембрани секреторних клітин. Автореф. дис. ... канд. біол. наук. Київ, 1995. 21 с.

11. Манько В.В. Са ${ }^{2+}$-транспортні системи внутрішньоклітинних депо секреторних клітин малоклітинних залоз. І. Ідентифікація. Матеріали міжнародної конференції, присвяченої пам'яті професора Шостаковської Ірини Василівни (11-12 жовтня 2002 р., м. Львів). Львів, 2002: 28-33.

12. Манько В.В. Методологічні підходи до дослідження $\mathrm{Na}^{+}-\mathrm{Ca}^{2+}$-обміну в екзокринних секреторних клітинах. Укр. біохім. журнал, 2006; 78 (1): 43-62.

13. Манько В.В., Бичкова С.В., Клевець М.Ю. Ідентифікація каналів вивільнення $\mathrm{Ca}^{2+} \mathrm{y}$ секреторних клітинах слинних залоз личинки комара-дергуна. Укр. біохім. журнал, 2004; 76(1): 65-71.

14. Манько В., Великопольська О. Ідентифікація пуринових рецепторів у секреторних клітинах слинних залоз личинки комара-дергуна. Вісн. Львів. ун-ту. Сер. біол, 2005; 40: 134-139. 
15. Манько В.В., Клевец М.Ю., Ларина О.А. Зависимость амплитуды тока $\mathrm{Na}^{+}-\mathrm{Ca}^{2+}$-обмена мембраны секреторных клеток от функциональной активности $\mathrm{Ca}^{2+}$-насоса в условиях внутриклеточной перфузии. II съезд биофизиков России (23-27 августа 1999 г., Москва): Тез. докл. Москва, 1999; 2: 537-538.

16. Манько В.В., Клевець М.Ю., Ларіна О.А., Стельмах С.В. Слинні залози личинки Chironomus plumosus як об'єкт для досліджень Са $^{2+}$-транспортних систем секреторних клітин екзокринних залоз. Биологич. вестн, 2001; 5 (1-2): 133-136.

17. Манько В.В., Клевець М.Ю., Федірко Н.В. Методичні підходи для виявлення трансмембранного струму натрій-кальцієвого обміну. Нейрофизиология / Neurophysiology, 1998; 30(4/5): 275-278.

18. Манько В.В., Король Т.В., Клевець М.Ю., Демків О.Т. Дослідження Са ${ }^{2+}$-транспортних систем секреторних клітин екзокринних залоз з використанням хлортетрацикліну. Вісн. Харк. ун-ту, № 488. Біофіз. вісн, 2000; 6(1): 79-81.

19. Манько В. , Ларіна О. , Клевець М. Залежність струму $\mathrm{Na}^{+}-\mathrm{Ca}^{2+}$-обміну плазматичної мембрани екзокринних секреторних клітин від функціонування $\mathrm{Na}^{+}-\mathrm{K}^{+}$-помпи. Вісн. Львів. ун-ту. Сер. біол, 2001; 27: 218-224.

20. Манько В.В., Стельмах С.В. Вплив рутенію червоного на вміст Са ${ }^{2+}$ у тканині слинних залоз личинки Chironomus plumosus. Вісн. Львів. ун-ту. Сер. біол, 2002; 29: 171176.

21. Слинченко Н.Н., Браткова Н.Ф., Костерин С.А., Черныш И.Г. Влияние эозина Ү на каталитическую и функциональную активность $\mathrm{Mg}^{2+}$, АТР-зависимого кальциевого насоса плазматической мембраны гладкомышечных клеток. Биохимия, 1998; 63(6): 812-819.

22. Adkins C.E., Taylor C.W. Lateral inhibition of inositol 1,4,5-trisphosphate receptors by cytosolic $\mathrm{Ca}^{2+}$. Current Biol, 1999; 9: 1115-1118.

23. Ashby M.C., Craske M., Park M.K., Gerasimenko O.V. et al. Localized $\mathrm{Ca}^{2+}$ uncaging reveals polarized distribution of $\mathrm{Ca}^{2+}$-sensitive $\mathrm{Ca}^{2+}$ release sites: mechanism of unidirectional $\mathrm{Ca}^{2+}$ waves. J. Cell. Biol, 2002; 158: 283-292.

24. Beutner G., Sharma V.K., Lin L. et al. The mitochondrial ryanodine receptor in rat heart: characterization of the subtype. Biophys. J, (Annual Meeting Abstracts), 2002; 82: 110.

25. Bootman M. D., Lipp P. Calcium signalling: ringing changes to the „bell-shaped curve”. Current Biol, 1999; 9: R876-878.

26. Cancela J.M., Gerasimenko O.V., Gerasimenko J.V. et al. Two different but converging messenger pathways to intracellular $\mathrm{Ca}^{2+}$ release: the roles of nicotinic acid adenine dinucleotide phosphate, cyclic ADP-ribose and inositol trisphosphate. EMBO J, 2000; 19(11): 2549-2557.

27. Cannell M.B., Soeller C. Sparks of interest in cardiac excitation-contraction coupling. Trends Pharmacol. Sci, 1998; 19: 16-20.

28. Giovannucci D.R., Groblewski G.E., Sneyd J., Yule D.I. Targeted phosphorylation of inositol 1,4,5-trisphosphate receptors selectively inhibits localized $\mathrm{Ca}^{2+}$ release and shapes oscillatory $\mathrm{Ca}^{2+}$ signals. J. Biol. Chem, 2000; 275(43): 33704-33711.

29. Hajnoczky G., Hager R., Thomas A.P. Mitochondria suppress local feedback activation of inositol 1,4,5-trisphosphate receptors by $\mathrm{Ca}^{2+}$. J. Biol. Chem, 1999; 274: 1415714162.

30. Inoue M., Bridge J.H.B. $\mathrm{Ca}^{2+}$ sparks in rabbit ventricular myocytes evoked by action potentials. Involvement of clusters of L-type $\mathrm{Ca}^{2+}$ channels. Cell. Biol, 2003; 92: 532-538.

31. Kidd J.F., Fogarty K.E., Tuft R.A., Thorn P. The role of $\mathrm{Ca}^{2+}$ feedback in shaping InsP $\mathrm{P}_{3}^{-}$ evoked $\mathrm{Ca}^{2+}$ signals in mouse pancreatic acinar cells. J. Physiol, 1999; 520: 187-201.

32. Knot H.J., Laher I., Sobie E.A. et al. Twenty years of calcium imaging: cell physiology to dye for. Molecular Interventions, 2005; 5: 112-127. 
33. Li Q., Luo X., Muallem S. Functional mapping of $\mathrm{Ca}^{2+}$ signaling complexes in plasma membrane microdomains of polarized cells. J. Biol. Chem, 2004; 279(27): 2783727840.

34. Lipscombe D., Madison D.V., Poenie M. et al. Imaging of cytosolic $\mathrm{Ca}^{2+}$ transients arising from $\mathrm{Ca}^{2+}$ stores and $\mathrm{Ca}^{2+}$ channels in sympathetic neurons. Neuron, 1988; 1: 355-365.

35. Park M.K., Ashby M.C., Erdemli G. et al. Perinuclear, perigranular and sub-plasmalemmal mitochondria have distinct functions in the regulation of cellular calcium transport. EMBO J, 2001; 20(8): 1863-1874.

36. Petersen O.H. Localization and regulation of $\mathrm{Ca}^{2+}$ entry and exit pathways in exocrine gland cells. Cell Calcium, 2003; 33: 337-344.

37. Petersen O.H., Burdakov D., Tepikin A.Y. Polarity in intracellular calcium signaling. BioEssays, 1999; 21: 851-860.

38. Rizzuto R., Pozzan T. Microdomains of intracellular $\mathrm{Ca}^{2+}$ : molecular determinants and functional consequences. Physiol. Rev, 2006; 86: 369-408.

39. Yao Y., Choi J., Parker I. Quantal puffs of intracellular $\mathrm{Ca}^{2+}$ evoked by inositol trisphosphate in Xenopus oocytes. J. Physiol, 1995; 482: 533-553.

40. Zimmermann $B$. Control of Ins $\mathrm{P}_{3}$-induced $\mathrm{Ca}^{2+}$ oscillations in permeabilized blowfly salivary gland cells: contribution of mitochondria. J. Physiol, 2000; 525(3): 707-719.

41. Zucchi R., Ronca-Testoni S. The sarcoplasmic reticulum $\mathrm{Ca}^{2+}$ channel/ryanodine receptor: modulation by endogenous effectors, drugs and disease states. Pharmacol. Reviews, 1997; 49(1): 1-52.

Одержано: 10.06 .2008 